(1)

繊維学 会誌

（昭和 44 年 5 月 第 25 巻 第 5 号 通巻第 281 号)

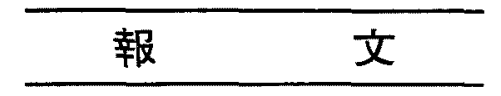

(昭和 43 年 11 月 13 日受理)

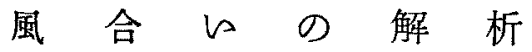

京都大学工学部高分子化学教室 川 端 季 雄

\title{
ANALYSIS OF HANDLING CRITERION
}

By Sueo Kawabata

(Department of Polymer Chemistry, Kyoto University, Kyoto, Japan)

The following four hypotheses are presented for defining "handling" or "feeling". (1) Handling criterion is used for many materials which are used for wearing or, if not, which have frequent chances of being touched by hand or by any other portions of the human body, (2) the main subject for the criterion is the mechanical properties of material, (3) the true judge of the criterion is the man who well knows about the mechanical properties relating with its end use, (4) the criterion depends on whether or not the mechanical properties are adequate for its usage.

It was discussed whether the criterion can be determined without human feeling following the hypotheses.

It is concluded that numerical evaluation of the mechanical properties is difficult at this stage because of its complex nonlinear properties. And author maintains that some careful checks of the nonlinear properties are important and effective to identify the handling grade of the tested material.

Some experiments have been done as an example of the above proposed method.

(Received November 13, 1968)

\section{1. 腥票}

風合いの良否という倸価が衣服用の布をはじめ，かな ク広い万面の材料について，ての材料の良否の判定や品 質評価に使用されている。特に高級な品筫の材料洼どこ の評俩が重要視されているようである。

しかし，問題はこの風合いの良否の判定基準が数值化 された明確なものでなく，篹くへきことには判定者自身 が，具体的に被駼物のどのよな性質を，何を基準にし て判定しているのかといらことを明確に説明できないと いら点にある。らつうは手で被験物を触ったりにぎった りしたときの受ける感覚で風合いの良否順位を洟めるの であるか，全く主観的で個人差の澈しいものかといえ ば，そうでるなく，何人かの同時判定の結果が注济一致 するといらからなんらかの客観性が存在していることは
確かである。しかしながら現在，風合いに関して少くと も明確なことがらは, 测定と判断が人間の感賞と頭脳で 行なわれているという点のみであって，その他の点は害 にめいまいである。風合いといらあのの定義すら確かで ない。

本諭文では，まず風合いとは何かといら点の検討から

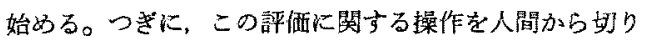
離して，人間の手の代りに湘定機を用い，頭脑の代りに たとえは計算機を用いよらといらような万法るもらろん 考えられるが、その内容の複雑さが予想されること述 ベる。

しかしながら，風合いの評価について少くとも現状で は上述のよらに客観的判断法を採用しなければ，工業製 品としての䄉維製品の性能設計ができない事態がいつま でも持続するのであるが，しかし客観化を安易に，たと 
えば適切でない测定結果からの数字の単なる統計的処理 で行ならことに㮛本的な誤りを执かす危险のかる点も本 論文で指摘するとともに, 客観化の可能性が確かに存在 し，その方法はきわめて注意深くめらねばならない点を 実験データによって示したいと思ら。

\section{2. 風合いに関する仮説の設定}

風合いとはいかなる評価法であるかという点につい て，四つの仮説を設けてみた ら判定が行なわれる材料に関してであるが，农服林料を 中心として皮革類からカーベットなど意外に広い材料に いすずれる風合いといら評価法が用いられている。それ ら材料火共通している点は，いずれも

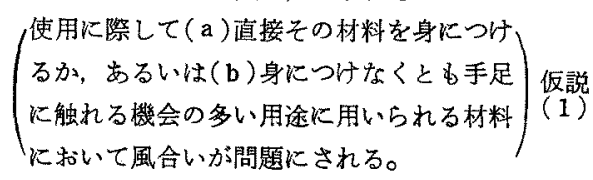

衣料材料は上述の (a)，(b)二つの条件にまたがるの で，もらろん風合いが評価ざれるが，たとえばかばん用 材料は身につけないが手足が触れる機会の多い用途に用 いられるので(b)k該当し, やはり風合いが問題にされ る。

次に，風合いとしてどのような量を測定評洒している のかといら点であるが，手で触れたり，にぎったりする 操作で判定されることからわかるよらに

（材料の力学的性質が判定の主たる対象である）

たとえば，布の吸湿性や保温性なども風合い判定に関 係するように思われているが，それは間接的であり，面 接には着心地に関係する性質である。すなから，後述す るように風合いは着心地につながっている。しかし，着

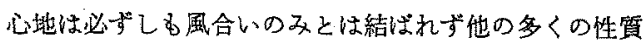
と関連している点に注意する必要がある。

次火，誰れが風合いの判定を行なっているのか将えて みよ5。風合いK客観的から一般的な判定基準がない以 上，判定は判定者の判断にのみ依存するので，この問題 は重要である。ここで現在，判定者に二つの型があるこ とを指摘したい。一つは，真の判定者であり，いまこれ をAとしよう。他の一つはAから判定法を学ぶ立場でこ れをBとする。たとえば，Aに布を志るBが，Aが行な う判定の結果を集積してその判定法を自然に学らのもそ の一例である。つまり，Bにとって布のある性筫がなぜ 風合いがよいといらことにつながるのかといらことの内 容には興味なく，ただそれらが結果として結びっくこと の知ればよいのである。Bに属する判定者は比較的多 いこれ愫観化への移行の㑯向を示しているようにも
みえるが，梙はそうでなく風合いという評洒をより複雑 にしている原因にもなっているように思われる。蟣維か ら布までの製造技術者にはBの立場の人が多いのである が，この場合，次の流通段階である，布の販艺会社がA の立場に立つかといらことも胥問である。貶売会社自体 もたとえば繾製業者など，次の流通機棈に対してBの立 場にあることが多い。このよらにたどると消費者がAの 立場に立つことになるがこれるまた疑問である。確が 原則的にはそうであるが，実際には消費者はそれ忹と製 品の性能に対して䍏門家であるとは限らないからであ る。㭙料の種類によってAは一体だれであるかは一概に 定められない。衣料材料の場合，消費者が自分自身で縫 製し，着用するような種類の布では消費者がAである場 合もあらら。しかし一般の消費者が各種の布を使用し比 較する頻度はそんなに高くないのでややはり專門的にこ うとた機会を多くるつ人達がAとみるべきである。すら ろん綎製が専門技術者や専門工場でなされる種類の布て は消費者の意見も知り，かつ释製も麦蔡に行ならこうし た専門技術者がAの立場偟立つであるらと思われる。A の立場が誰であるかを確認することは問題を複雑にする ことを防止するらえで重要である。この点に関し，次の 仮説を設ける。仮説 (2)から

$\left(\begin{array}{c}\text { その材料の力学的性質を便用時の性能 } \\ \text { （消費性能）との関連において熟知す } \\ \text { る人が風合いの真の判定者である。 }\end{array}\right)$ 仮説 (3)

衣服材料において䋖製のしやすさといらことも風合い の判定に加方るといら意見むあるが、これは稌製芰術者 からの意見が強められた場合の一例ですって䋖製のしや すさむ広義で解釉すれば消費性能の一つであるから、こ れる仮説( 3 )を亳付けるるのであらう。

ここで強調したい点は，風合いがよいこと，たとえば よい手触りといらことは単にばく然とした，そして全く 官能的な快感を指しているのではなく，もっと実用的考 慮が先に立った判断であるということである。すなわち たとえば布の風合い判定に際しては，判定者は手触りと いら判定法から得た力学的量をるとにその布が衣服に仕 立てられたときの型くずれのし難さ（寸法の安定性）， 着心地のよさ,さらには縫製のしやすさなどの性能を過 去の経験を総合して頭脳といら計算機でごく短時間に計 算していると考えてよいである5。仮説 (3)からさらに 次の仮説が導かれる。

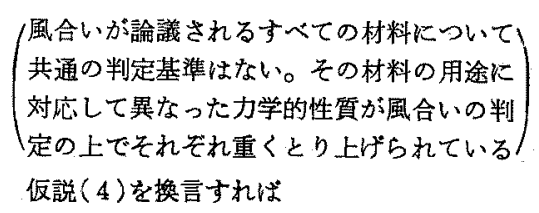
仮説 
村料の用途に底してそれをれに適合し

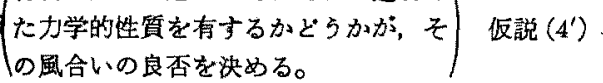

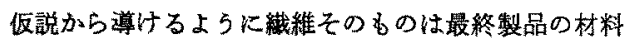

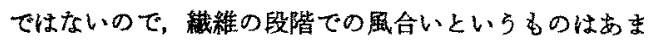
り諭議されないが，ないわけではなく、たとえば生約の かせの取引に整して，かせを握ってその会合いから生系 の願位をつけて洒格が定められるという。この場合，単 に快感だけでその順位をつけているとはとちてい考克ら れず，前述の仮説(3)，(4)が維維の段階で，かせとい う集合体で実行されているるのと思われる。

ここで，風合いの判定法の一つとして間接的方法が比 較的広く行なわれていることを知っておく必要がるる。 つまり，すでに理想的風合いる有するとされる材料と比 較して，その理想材料に近い感しがあるかどらかを手糔 りで調ベる方法て，たとえば羊毛物と同じ風合いを合 成維維織物でもたせようとするとき，風合いの良否の基 準は羊毛織物に近い感じを与えるかどうかに方る。こ も一つの風合いの判定法であるが，上述の仮説 (1)〜 （4）で述いた風合いの良否の判定が絶対的風合いとすれ ば、これは相対的風合いといえる。この場合には，仮説 （2）のみが適用され，閏題は比較的簡単になる。仮説 （1）～(4)で定義される絶対的風合いを新しい風合い, この相詨的風合いを旧来の風合いであるといら説いあ $\Xi^{1)}$ 。

\section{3. 風合いの判定過程について}

仮説(2)が正しい々すれば，風合い之材料の力学的性 質との間には，少くともとの材料に関して両者を結ふ固 定された咸係が存在する誖ずする。

現実に風合いの判定をより具体的にするため，手触り から受ける感賞を細別して，たとえばがラ感とかシャリ 感とかいら上らに具体化して判定されていることが多 い。これも仮説 (3)，(4) の具体的実行法の一つで南 る。

ここで問題点を一つ挙げたい。こうした従来からの， どららかといえば主観的な感覚にたよる万法で行なわれ てきた風合いの判定法を，仮説 (4)’满たす判定法で あると認め，かつその結果を正しいと認めるかとうかと いら点である。もし謵めるならば今後の目標はこの判定 法をでるだ客観化主るため，支の判定結果を具体的 な計測可能な力学量と結びつけることに较ればよい。し かし，この点について筆者は必ずしも従来の判定結果に こだるる必要はないと教る。そして，「舅合いのよさ」

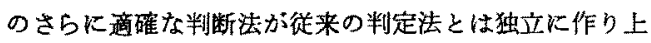
げられる可能性があると思われるし，作り上げられるへ

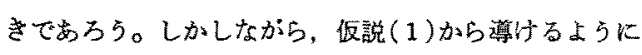
風合い性人間の感党以直接関係するものであるから，少 くとも手で触って判定する感覚法は彷来の維験の集程て まり，その判定に対してどの上らな力学量が刘応してい るのかを娭徱するのは前速の新しい風合いをさくるため にもるらるん重要であるが，それがすでてではないこと 学強調したい。

しかし，少くとも現在，手で能った感覚から判定され る風合いと湘定可能な力学量を関係つけよらといら要請 があるか，この場合すくに思いつくのは雨者の因果関係 になんらかの統計的相閣をつけよらといら処理法てあ る。感覚による風合い判定結果を順位つけて数值化し， 一方でなんらかの力学的测定値を得て統計观理をする方

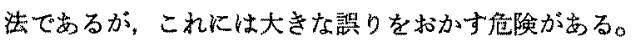

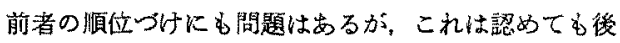

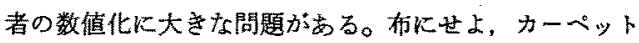
にせよ人間が身につけたり触ったりしている材料の多く

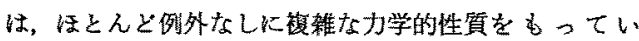
る。たとえば，第 1 図は織物の力学的性筫の例を示して いるが，上段は一軸拘束の二俥伸長特性（第２因参照） である。因の上らにき和めて顕著な非線形特性を示して いることがわかるが，たとえばいま織物を引張って受け る感覚はこのヒステリシスを含も全過程をらくんでいる はずであるこのときこ禹の数值化はどらすればよい のか。しかる，この第1図で、たとえばたて軸は力に比 例した目盛である。しかし人間の感覚はこのように力に 対して直線的，もしくは比列的でなく，たとえば対数的 であるるうに非線形的感受珄をむつことが予想される。 もちろんこの場合です第1図とはある写像関系にあるは ずであるから，問題は因の讃識法に絞られるが，このよ らな図形を感じとり同時に仮説 (3)，(4)を判断す苛頍 腷の思考迩程を明らかにしない限り，まず計算機を人間 にとってかえよらとい5ことは因難である。この思考過 程を省き，前述の因果网係のみをとりあげてす現在の計

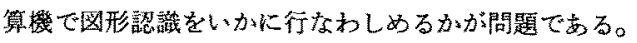

最近, 織物の力学的性質の研究の発展にともない，織

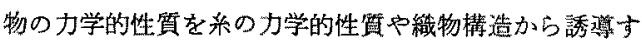
ることが可能になってきた。第1図は羊毛，ポリエステ ル，綿からなるは经同じ棈造の三種の蟣物につにてそれ それ上段に前述した。一軸を拘束した二軸伸長特㤬，下

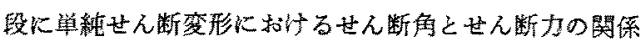
を示すが，困で寒線は測定曲線，点線は理諭計算曲線で る。

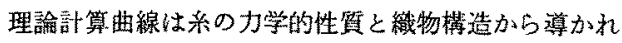
たものでこれに関する理論は最近きわめて進んだ2ー8)。 これからるかかるよらに引張特性むせ九断特性も来の力 
Strip Biaxial Tensile
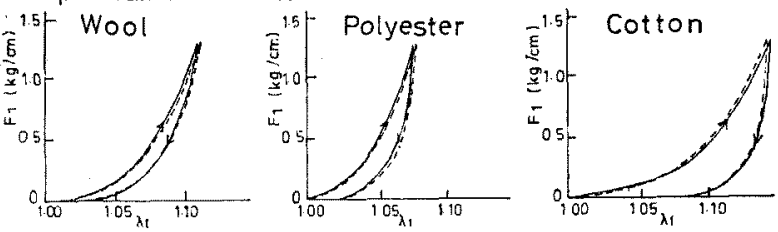

Simple Shear
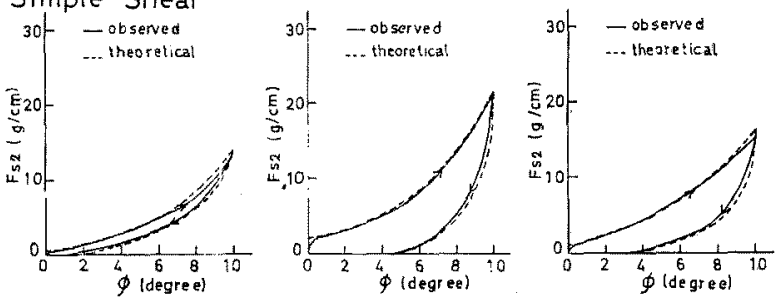

Fig. 1. Comparison between mechanical properties of wool, polyester and cotton plain woven fabrics. These three fabrics are woven carefully so as to obtain the same structure using yarns of same counts.

Solid lines are experimental and dotted lines the theoretically calculated lines.
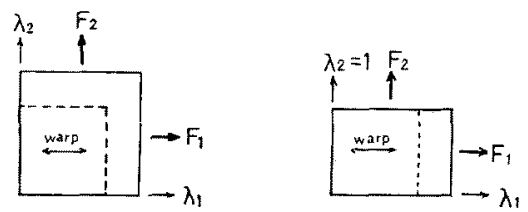

Uniform biaxial tensile

Strip biaxial tensile when the case $\lambda_{1}=\lambda_{2}$

Fig. 2. Examples of fundarnental mechanical properties.
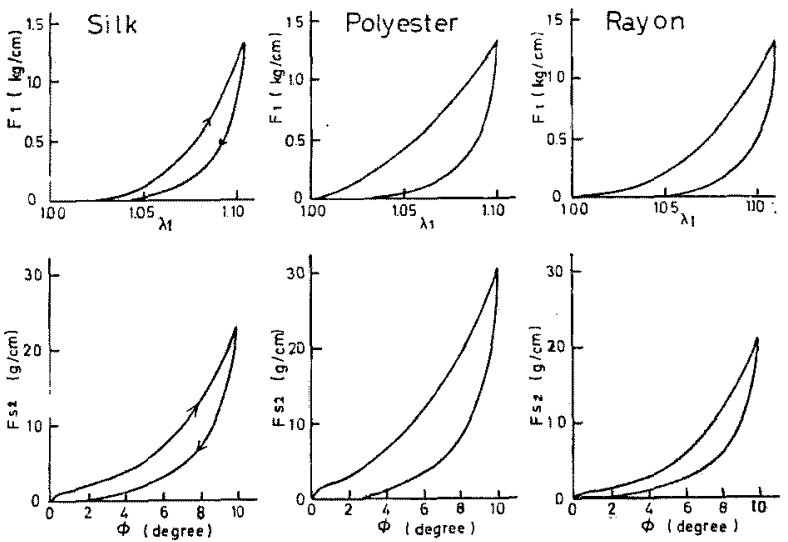

Fig. 3. The two left side figures show the properties of silk crape and those of the middle and right are polyester crape and rayon crape respectively.

The deformation types are same as figure 1.
学的性質の織物構造から導かれるので，雨 者の間化㤬密接な関係があるのは当然であ る。いまなんらかの方法によってこれら を数値化して風合いとの間にそれぞれの相 関関係を求妨，いずれの性質が上り強く風 合いに関係するかということる計算してる 両方の性質が本来密接儿結ばれている以 上，数值化の方法に上って片方か強い相関 をるてば他も同様に強い相関をむらことも あり得るわけで，この点を注意しないと統

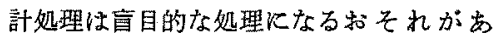
る。

第1図からみてかかるように三種の織物 について，この二つの特性で比較しても顕 著な盖が范る。この差が風合いにひびくの は当然のことといえる。

問題はこの差の処理法をいかにすべきか といらことにかかる。

\section{4. 風合い判定の客観化に関して,} 現段階におけるーつの方法と実験

前節に扎いて力学特性のもつ複雅さのゆ えに筆者はその特性を数値化しょらとする ことの四難さを指通した。数値化にこだわ るのは計算や統計処理にこだわるからで, 現段階では計算機の能力の点からも，まず 基本的力学特性について第 1 図の上万に図 形比較し，観察することから始めるのも一 つの方法である思う。第 3 図は織物のな かでも高級品の一つである一越ちりぬん （絹）とこれに似せて作られたポリェステ ル瀻維からの織物，および同じくレーヨン の織物の三者の比較で，第 2 图に示す㚆形 椂式のらち一軸拘束の二軘伸長と単純せん 断について比輍している。ただし前者では たて糸に沿ら方向の力の死をしている。 ヒステリシスの大きさ，初期特性の曲線形

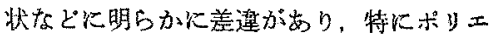
ステル織物にそれが著しい。

周知のよらにこの種の織物はたて系方向 とよこ糸方向の引張特性が著しく巽なる巽 方性を有している。均等に二軸方向に伸長 した場合のたて方向の力（实線）とよこ方 向の力 (点線) 古同時化示したのが第 4 図 の上段で，下段は第3図と同じく単純せん 断特性である。第 3 困の三種の織物に加兄 
Uniform Biaxial Tensile
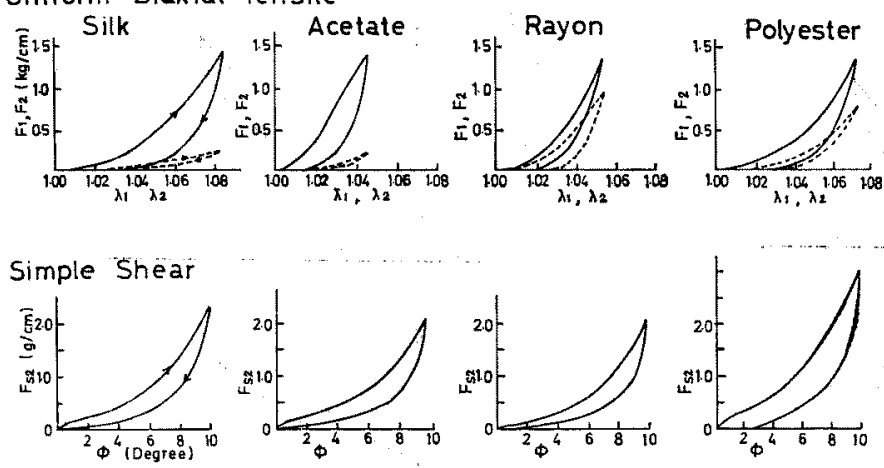

Fig. 4.... Acetate rayon crape is added. The upper side correspond to uniform biaxial deformation, and the lower is the same as of figure 3. Acetate rayon crape is very close to silk crape as seen in this figure.

てアセテート織物も比較しているが，アセテート織物は 絹織物とよく但た性質を示すことがわかる。事実，こう した生地を扱う人達でも織物を触って簡単には両者の区 別がつかないことがあるという。これは単に引張とせん

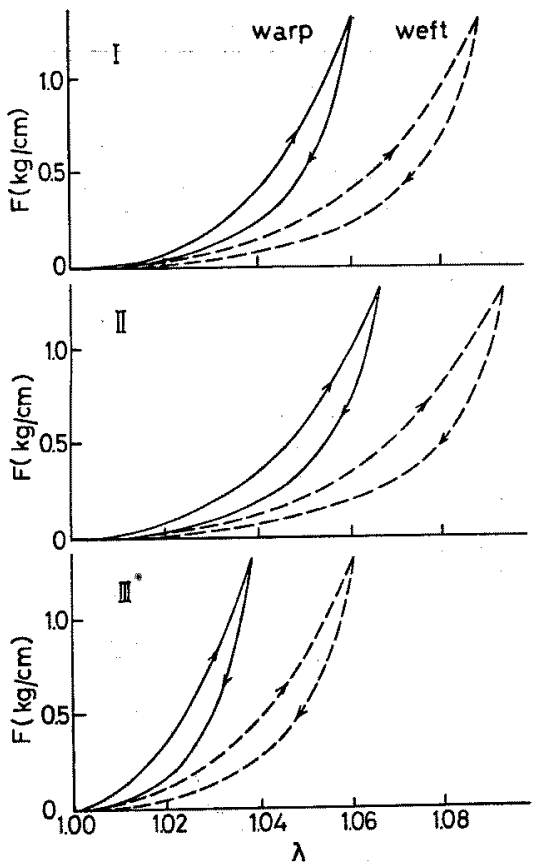

Fig. 5. Uniaxial tensile properties of sample 1 , II and III. I and II are very close to each other. I, II and III have almost same structure to each other and are used for men's suits.
断のみを比較しただけであるが、こ れら両者で似ていても他の性䝷で異 なることがあり，上述の綟とアセテ

ートも曲げの特性で差がつく。

さらに精密な比較の一例老次に示 してみよう。試料としてはぼ同じ織 物榡造をむつ紳士用スーッ地三種 $\mathbf{I}$ ， II， III 選んだ。

試料I；羊毛織物：風合いがよい と判定されている。

試料 II；羊毛織物：試料Iにくら べわずが風合いが劣ると判定ざれ ている。

試料 III ；羊毛 $50 \%$ ，ポリエステル 50\%混紡第の織物：風合いは I，II にくらべ格段恶い。

第 5 目は試料 I，II，IIIのそれぞれ一軸伸長特性で央線 はたて糸方向, 点線はよこ糸力向を示す。亚が明らかに 異なるが I，II の区別はつけにくい。曲線の傾きが ややほるやが欢えるが，これは楧造に若千の相逵があ

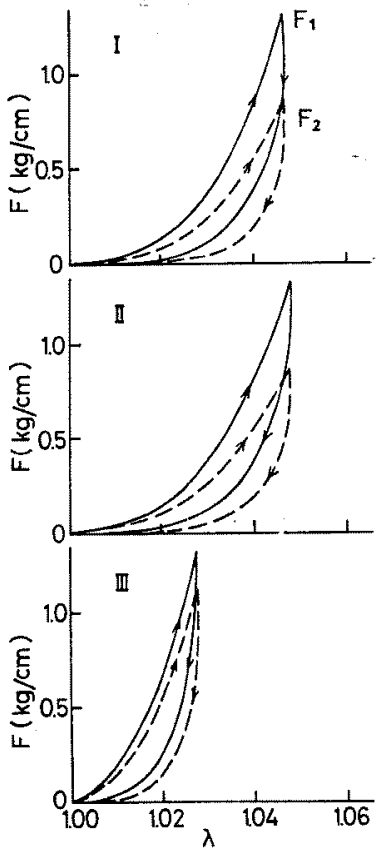

Fig. 6. Uniform biaxial tensile properties of $I$, II and III. II shows slightly quick increasing of force in relatively small deformation region. 

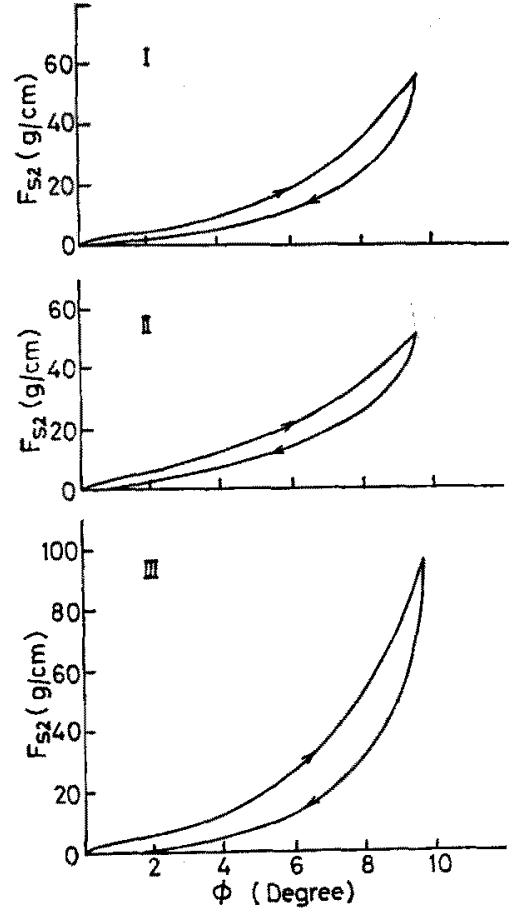

Fig. 7. Simple shear properties of I, II and III.

るためですることは理論的にも匴ける。初期の曲線には ほとんど相㸃がない。

第 6 因性均等二軸伸長特性である。正はるらろん巽な

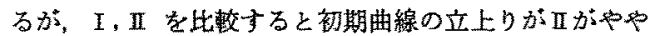

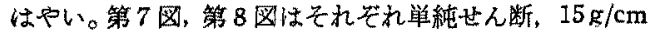
の強制引張荷重下゙で伸長 $\lambda_{2}$ を年えた状熊でのせん断

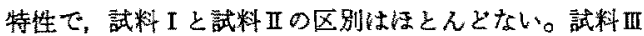
は傾斜名急であるがえは織物に「かたさ」の感じ与

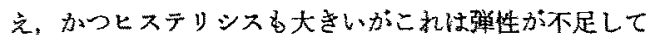

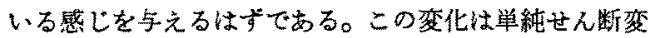

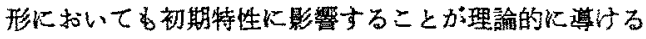
ので，その初期部分を比較してみると第9图のよ5にあ

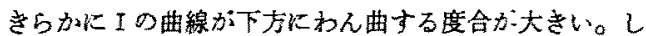
加も世ん断角方 $9.5^{\circ}$ 付近になると雨曲線は一致し，同 じ「せん断かたさ」をるつ。これはあきらかに䋘物の着

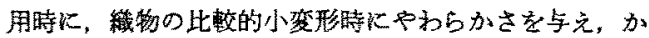
つある程橆以上の大変形時にはかたいかけで,この性筫 が着用機能上すぐれているこらはわれわれに名認められ 万。

均等二融伸長，単純せん断でみられるようなこうした 初期特栍の然抗が小さい圭たる原因の一つとして，理諭 からは系の横区に刘する王縮性が大きいためであること
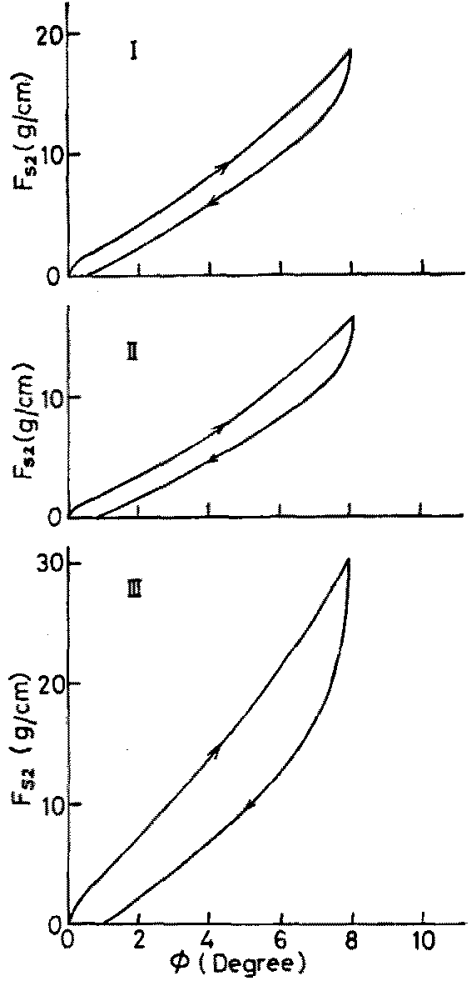

Fig. 8. Shear properties of I, II and III under constant stretch load $W=15 \mathrm{~g} / \mathrm{cm}$ along perpendicular direction to the one of shearing force.

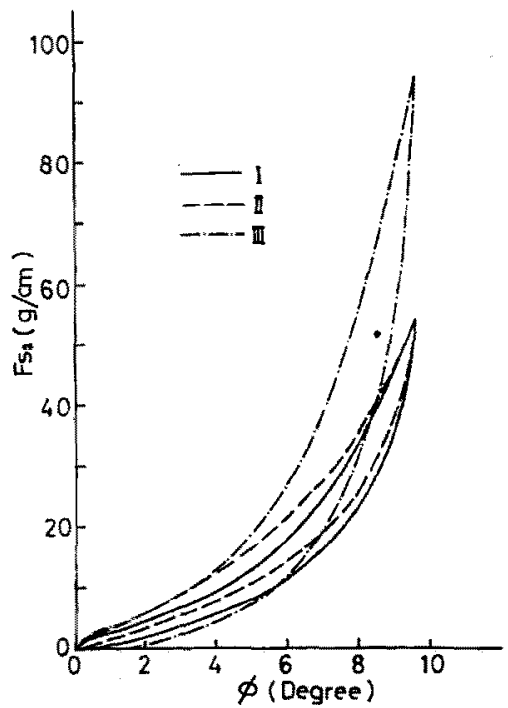

Fig.9. Comparison of the three curves shown in figure 7. I moves below of the others in relatively small deformation region. 
が誘導される。

そうした性質が直接現われる布の王縮性を比較してみ よう。第 10 四はよこ軸に厚みを、たて軸に圧力をと ク，I，II，IIの特性を重わて示しているが，IIが最む愿 いこえれは蟣物瀞造の若干の違いに基つくものである が，それよりる注意すべきことはIの曲線がなめらかに 上昇しているのに対して四ははじめ低く急に立ち上りは じるるIIはI とIIIの中間ししくはややIIIに近いといえ る。

かるくこの布に手を触れたときを考えよう。Iは 比較して弱い王力 $\left(4 \mathrm{~g} / \mathrm{cm}^{2}\right.$ 付近の圧力がその境界点) では愿い布でる。しかし，それ以上では逆に Iは「薄 く」なる。この現象から明らかにわかることは，IはII
に対してやわらかい触感を与えるであるちといらことで ある。

第 11 図は曲げ特性であるがエとIIの差違はない。さ らに與味あるのは亚は压縮に和いてすらとステリシスが 大きいことである。引張りに括いても，曲げにおいて も，またせん断においてもこうしたとステリシスは観測 されるがこれらはすべて織維閶の摩擦係数の大きいこ とに基因していることが理諭的に証明される2 ?

第 12 図は第 10 図の王力ピーク点を重ねて比較したも のでாはむしろ正の性質に属することがかかる。

これらの布の風合いを従来の力法で此較し順位をつけ た専門家（はじめのべたBに属する判定者）に判定の内 容をたずねなところ，事実このIと正の布はいくつかの

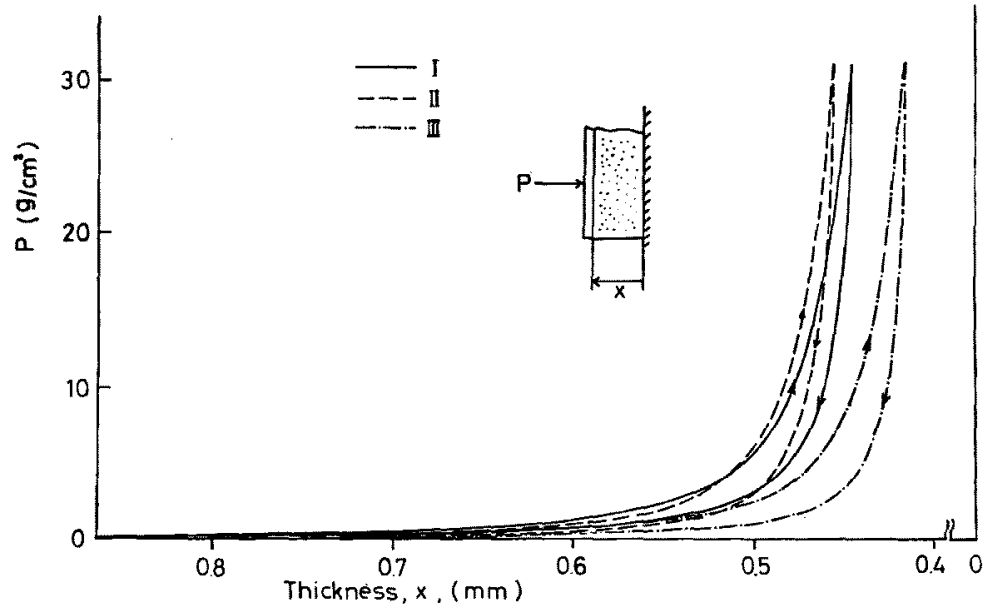

Fig. 10. Compressibillity of $I, I I$ and III. Soft feeling is be given by $I$.

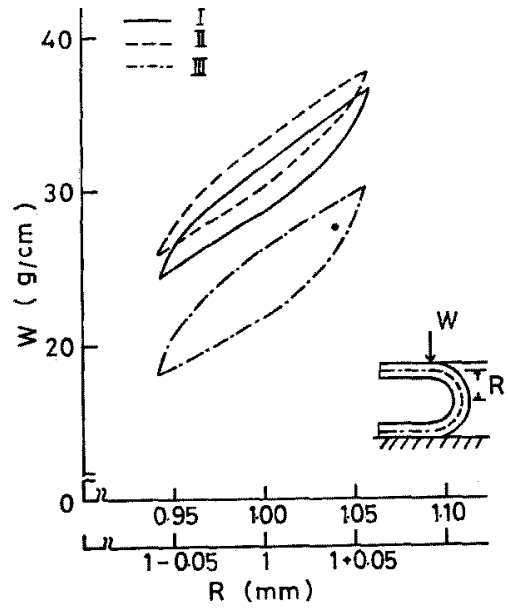

Fig. 11. Bending properties of $I, I I$ and III. I and II are almost same.

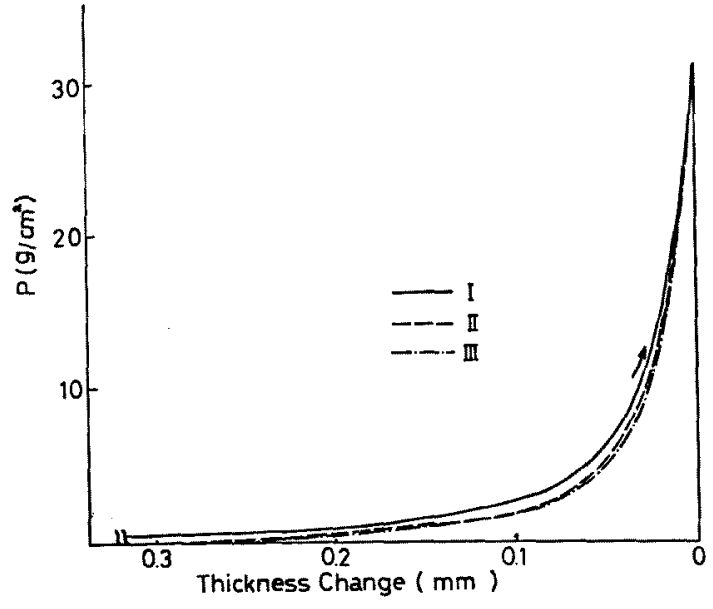

Fig. 12. Comparison between the properties of I, II and III shown in Fig. 10. 
項目の判定は同じでただ表面の手触りのみに若干の差が あるといらことであったが，以上の測定例はそれを裏付 けるばかりでなく，それ以上の情報を与去ている。

\section{5. 結 語（風合いの設計へ）}

風合いの良否という特性は, 綫維製品の重要な性能の 一つである。今日，近代的工業で製品の性能設計ができ ない工業分野はまれである。瀻維製品の風合いが前近代 的方法で行なるれている慣習は早急に改善されるべきで あらら。風合いに神秘性をもたせるのは測定技術の立遅 れを自ずから認めているむのといえよう。

ここで重要なことは風合いを適確に力学量測定によっ て判定しようとする際，たとえそれが手触りによる風合 い竞よく表見し得る方法でめってる，複雑な力学量をと ら劣ていてはならない。できるだけ基本的変形, たとえ ば前例にあげたよらな変形がその例であるが，そらした 変形汇とどめて和く必要がある。それは，解析の困難な 条件ではたと充風合いが判定できてもそれをその判定に 基ついてて風合いを制御するところまで役立てることはで きないからである。

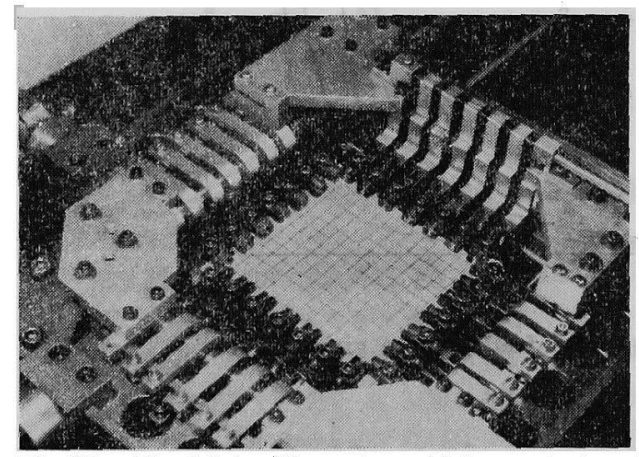

Fig. 13. Biaxial tensile tester which was designed by S. Kawabata etal.

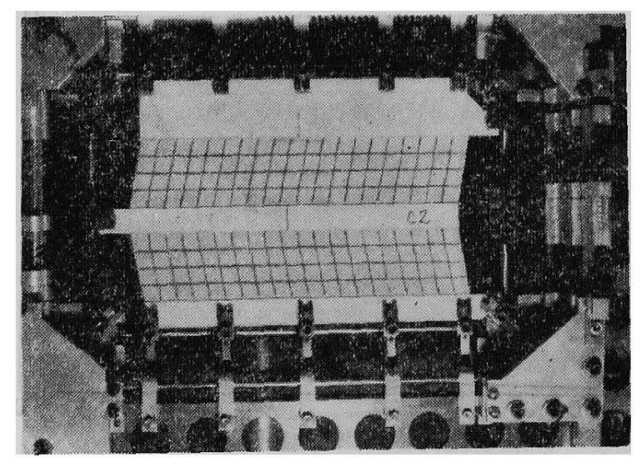

Fig. 14. Shear deformation testing using the biaxial tensile tester.
著者は3において図形の比較といら方法をとったが， この方法は将来の計算機の進歩によっておそらくこれを 計算機にとってかえることは可能になるであろうと思わ れる。

瀻維が系になると系としての新しい力学的性質が生ま れる。ささらに，亲が織物になると織物の性質はまた糸の それとは大きく異なって新しい性質をるつ。こうした変 化を瀻維の力学的性質から糸中織物の構造を考慮に入れ て理論的に計算できるようにすることが，一方において 風合いの設計への重要な準備である。

最近, 筆者らの研究グループに括いててる織物の弹性的 性質, 粘弾性的性質が絨維や系のそれとどのように関係 するか，また織維から系への变化はどうかといら問題に ついて究研を進めて拈り，たと光ば，織物については， 采の 1）引張特性，2）糸への横圧による系の圧縮特性, 3）二本の交差する系の交差角変化に対する抵抗トルク

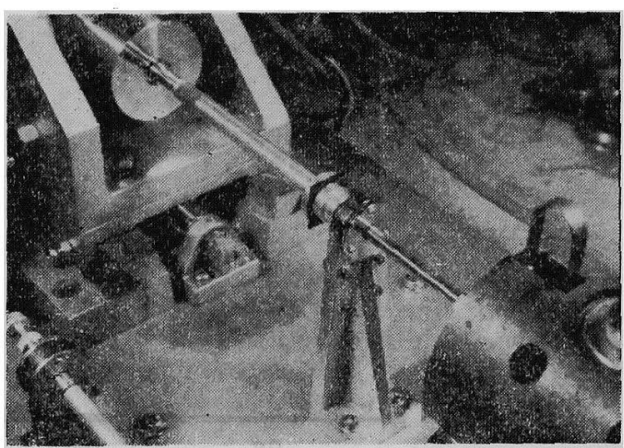

Fig. 15. Compression testing. Test specimen is compressed between two rods. The right rod is connected with deformation detector, and the left one with force detector. The compressive motion is drived by electric current in magnetic field. The apparatus was also designed by S. Kawabata.

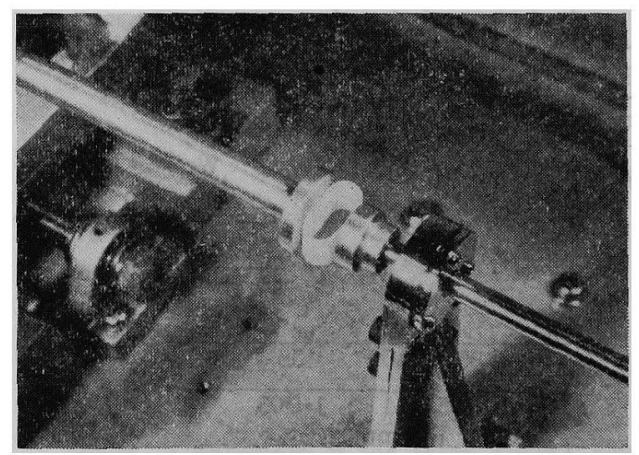

Fig. 16. Bending testing using tho same apparatus as in figure 15. 
特性，4）織物の構造すなわち，采密度と織縮又率を導 入して第 1 図のよ5に点線で示した計算曲線が理墖計算 によって図のよらに精度离く求めることができるよらに なっている。

また，系の引張特珄や抵抗トルクの特性も㵶維の力学 的性質，まさつ係数などの物理的性質から理論的に求め る研究も非常に進えで扣り, 緎維の力学的, 物理的性質 から織物の力学的珄質を理論計算できる段階にまでいた っている。たと充ば、第1図ではポリエステル織物の引 張特性は羊毛のそれによく似ているが，世ん断特性に大 きなひらきがある。これは㵶䧽の摩擦係数の差にもとず くことは理論的に計算でさるよらになっている。したが って，ポリエステル瀻維の摩摖係数を故良すれば羊毛織 物の特性に近づけることはできるが，また，摩擦係数を そのままにして，どのような方法をとり，どのような構 造にすればせん断変形特性を羊毛に近づけ得るかといら こよを試みる計算もできるるらになってきた。

こうした繊維集合体の弾性や粘弾性の笢研は現在さら に進みつつあるので, 風合いの判定に関する研究を今後 発展させれば䋘維製品の風合い設計が可能になるである らと思われる。これは夢として考えるべきでなく，現実 に製品設計ができない㵶維工䅈によって緊急に解洪しな
ければならない立ち遅れた問題であることを認識した い。そうした進んた段階にいたると，むはや風合いとい ら䓂葉は消減するであるら。すなわら，いくつかの製品 性能または材料性能に分解されるはずである。

付記 第 13 図に引張試験, 第 14 図にせん断試験の方 法を写真で示した。装置はいずれる筆者らによって試作 された二軸引張試験機である゙す。

第 15 図，第 16 函は玨縮括よび曲げ試験の精密測定装 置でやはり筆者によって最近試作された ${ }^{103}$ 。

\section{文献}

1) 藤野清久; 私信

2) 丹羽, 川端, 河合; 緎機学誌, 19, T157（1966) 20, T 12, T 258, T 279, T 317 (1967)

3）川端, 丹羽, 河合 ; 第 20 回日本緎維機械学会年 次大会講演前刷，180（1967）

4）川端，丹羽，河合 ; 日本緎維機械学会講钼論文集 No. 21, 124 (1968)

5）丹羽，川端，河合；闹上，130（1968）

6）高力, 丹羽, 川端，河合；同上，136 (1968)

7) 丹羽雅子; 京都大学工学博士学位論文

8）川媒季堆；第 16 回高分子夏期大学請演要旨集, E17 (1968)

9）坂口，川端，河合，砏；材料，17，356（1968）

10）川端季婎; 末発表 